\title{
Absence of $\lg \mathrm{D}^{-} \mathrm{CD} 27^{+}$Memory B Cell Population in X-linked Hyper-IgM Syndrome
}

\author{
Kazunaga Agematsu, ${ }^{*}$ Haruo Nagumo, ${ }^{*}$ Koji Shinozaki, ${ }^{*}$ Sho Hokibara, ${ }^{*}$ Kozo Yasui, ${ }^{*}$ Kihei Terada, ${ }^{\star}$ Naohisa Kawamura, $\$$ \\ Tsuyoshi Toba, "Shigeaki Nonoyama," Hans D. Ochs, ${ }^{\star *}$ and Atsushi Komiyama* \\ *Department of Pediatrics, Shinshu University School of Medicine, Matsumoto 390, Japan; ${ }^{\ddagger}$ Department of Pediatrics, Kawasaki Medical \\ School, Kawasaki, Japan; ${ }^{\S}$ Department of Pediatrics, Osaka Rosai Hospital, Osaka, Japan; "Chiba Children's Hospital, Tiba, Japan; \\ "Department of Pediatrics, Tokyo Medical and Dental University, Tokyo, Japan; and **Department of Pediatrics, University of \\ Washington Medical School, Seattle, WA 98195
}

\begin{abstract}
The present study analyzed peripheral blood B cell populations separated by IgD and CD27 expression in six males with X-linked hyper-IgM syndrome (XHIM). Costimulation of mononuclear cells from most of the patients induced no to low levels of class switching from IgM to IgG and IgA with Staphylococcus aureus Cowan strain (SAC) plus IL-2 or anti-CD40 mAb (anti-CD40) plus IL-10. Measurable levels of IgE were secreted in some of the patients after stimulation with anti-CD40 plus IL-4. Costimulation with SAC plus IL-2 plus anti-CD40 plus IL-10 yielded secretion of significant levels of IgG in addition to IgM, but not IgA. The most striking finding was that peripheral blood $\mathrm{B}$ cells from all of the six patients were composed of only $\mathrm{IgD}^{+} \mathrm{CD}^{-} 7^{-}$ and $\mathrm{IgD}^{+} \mathrm{CD}^{2} 7^{+} \mathrm{B}$ cells; $\mathrm{IgD}^{-} \mathrm{CD} 27^{+}$memory $\mathrm{B}$ cells were greatly decreased. $\mathrm{IgD}^{+} \mathrm{CD} 27^{+} \mathrm{B}$ cells from an XHIM patient produced IgM predominantly. Our data indicate that the low response of IgG production in XHIM patients is due to reduced numbers of $\mathrm{IgD}^{-} \mathrm{CD}^{2} 7^{+}$memory B cells. However, the IgG production can be induced by stimulation of immunoglobulin receptors and CD40 in cooperation with such cytokines as IL-2 and IL-10 in vitro. (J. Clin. Invest. 1998. 102:853-860.) Key words: hyper-IgM syndrome • memory B cells $\bullet$ CD $40 \cdot$ CD27 $\bullet$ CD70
\end{abstract}

\section{Introduction}

Hyper-IgM syndrome is characterized by an increased susceptibility to infections and markedly decreased levels of serum $\operatorname{IgG}, \operatorname{IgA}$, and $\operatorname{IgE}$, but normal or elevated levels of $\operatorname{IgM}(1,2)$. An X-linked form of hyper-IgM syndrome (XHIM) ${ }^{1}$ has been shown to result from mutations in the CD40 ligand (CD154) gene (3-5). CD154 is a TNF-like type II membrane protein expressed on the surface of activated T cells (6). CD40 is ex-

Address correspondence to Kazunaga Agematsu, Department of Pediatrics, Shinshu University School of Medicine, Asahi 3-1-1, Matsumoto 390, Japan. Phone: 0081-0263-37-2642; FAX: 0081-263-37-3089; E-mail: agemats@gipac.shinshu-u.ac.jp

Received for publication 11 March 1998 and accepted in revised form 17 June 1998.

1. Abbreviations used in this paper: MNC, mononuclear cell; RT, reverse transcriptase; SAC, Staphylococcus aureus Cowan strain; XHIM, X-linked hyper-IgM syndrome.

J. Clin. Invest.

(C) The American Society for Clinical Investigation, Inc. 0021-9738/98/08/0853/08 \$2.00

Volume 102, Number 4, August 1998, 853-860

http://www.jci.org pressed ubiquitously throughout the B cell lineage (7). Triggering via CD40 on B cells by CD154 stimulates B cell proliferation (8) and germinal center formation (1, 9-12), and promotes the expansion of the memory B cell pool $(13,14)$. The CD40-mediated signal in combination with IL-2 or IL-10 stimulates B cells to secrete $\operatorname{IgG}, \operatorname{IgM}$, and $\operatorname{IgA}(15,16)$ and in the presence of IL-4 to secrete $\operatorname{IgE}(17)$. The vital role of CD40 molecule for immunoglobulin production is underlined by low levels of serum IgG, IgA, and IgE in XHIM patients. There is, however, little information on the reason for the inability of various $B$ cell activation systems, including stimulation via CD40, to produce immunoglobulins, even though CD40 in the patient B cells is intact and the CD40-mediated signal transduction in B cells is not impaired $(3,4)$.

Recently, we have demonstrated that the interaction between CD27, which belongs to the NGFR/TNFR family (18), and CD27 ligand (CD70), a member of the TNF family (19) that is expressed not only on activated $\mathrm{B}$ cells but also on $\mathrm{T}$ cells, especially activated $\mathrm{CD}^{+}{ }^{+} \mathrm{CD} 45 \mathrm{RO} \mathrm{T}$ cells (20), can enhance immunoglobulin production by $\mathrm{B}$ cells $(21,22)$. Furthermore, adult peripheral blood B cells can be divided into three discrete subtypes: $\operatorname{IgD}^{-} \mathrm{CD} 27^{+}, \mathrm{IgD}^{+} \mathrm{CD} 27^{+}$, and $\mathrm{IgD}^{+} \mathrm{CD}_{27}^{-} \mathrm{B}$ cells. $\mathrm{IgD}^{-} \mathrm{CD} 27^{+} \mathrm{B}$ cells produce $\mathrm{IgG}, \mathrm{IgM}$, and $\operatorname{IgA}$, whereas $\operatorname{IgD}^{+} \mathrm{CD} 27^{+} \mathrm{B}$ cells predominantly produce $\operatorname{IgM}$ (23). The striking function of CD27 in B cells is that CD27/CD70 interaction promotes the differentiation of CD27 memory B cells toward plasma cells $(24,25)$. To date, the information available from XHIM patients is not conclusive concerning the generation of memory $\mathrm{B}$ cells in the absence of CD40 ligation. Little is known as to whether a lack of memory $\mathrm{B}$ cell response represents the impaired $\mathrm{IgG}$ and $\mathrm{IgA}$ production in the disorder.

In the present study, we have analyzed peripheral blood cells in XHIM patients with the surface phenotype of memory $\mathrm{B}$ cells using CD27 as a memory marker, and discuss the role in CD40/CD154 interaction in the generation of memory B cells.

\section{Methods}

Patients. The patient population ranged from 6 to $24 \mathrm{yr}$ in age. The clinical diagnosis of XHIM was made by the following criteria: $a$ ) males; $b$ ) onset of recurrent infections before $2 \mathrm{yr}$ of age; $c$ ) low serum IgG and IgA levels, and normal to elevated serum IgM concentrations; and $d$ ) normal numbers of peripheral blood B cells. Ages of six patients are given in Table $\mathrm{I}$, and the ages and serum immunoglobulin levels at the time of diagnosis before $\gamma$-globulin replacement therapy are shown in parentheses. CD40 expression on CD19 ${ }^{+} \mathrm{B}$ cells analyzed by the flow cytometry was normal in all patients (data not shown). Routine clinical laboratory studies and treatment including immunoglobulin replacement therapy were performed at the referring hospitals.

Sequence analysis of genes coding for CD154. Isolation and char- 
acterization of CD154 cDNA were described previously $(3,26)$. Briefly, total RNA was extracted from activated lymphocytes of patients and reverse transcription of CD154 mRNA to cDNA was done. The cDNA was amplified by PCR using primers at the $5^{\prime}$ and $3^{\prime}$ ends of the coding region of the CD154 gene. The PCR products were sequenced using the dideoxy chain termination methods with an automated DNA sequencer (Perkin Elmer, Urayasu, Japan).

Antibodies and reagents. Anti-CD27 mAb (8H5; IgG1), which does not block the ligation of CD27/CD70 and anti-CD70 $\mathrm{mAb}$ (HNE51; IgG1), were previously described (21, 27). Polyclonal anti$\mathrm{IgD} \mathrm{Ab}$ was purchased from DAKO Japan (Tokyo, Japan). FITCconjugated CD40 mAb, PerCP-conjugated CD20 mAb, and APCconjugated CD19 mAb were from Becton Dickinson (Mountain View, CA), and purified anti-CD40 mAb (MAB89, IgG1) from Immunotech (Westbrook, ME). Anti-CD154 mAbs (1.7 and 106) and CD40-Fc fusion protein were gifts from T. Siadak and A. Aruffo (Bristol-Myers Squibb Pharmaceutical Research Institute, Seattle, WA) and $5 \mathrm{c} 8$ was a gift from Biogen (Cambridge, MA). Conjugation of biotin to anti-CD27 mAb was performed by the standard technique using $N$-hydroxysuccinimido-biotin (Sigma Chemical Co., St. Louis, MO) in our laboratory. Staphylococcus aureus Cowan strain (SAC) was obtained from Sigma Chemical Co., IL-4 and IL-10 from Genzyme (Boston, MA), and IL-2 from Takeda Seiyaku Co. (Osaka, Japan).

Cell preparation. Heparinized cord blood was collected after obtaining informed consent. Peripheral blood samples of children at various ages were obtained at the time of clinical examination and were finally found to have no immunological abnormalities. Peripheral blood samples were also collected from healthy volunteers and XHIM patients. Mononuclear cells (MNCs) were isolated from the cord blood and peripheral blood by Ficoll-Hypaque (Pharmacia, Piscataway, NJ) density gradient centrifugation. The MNCs from healthy volunteers were separated with $5 \%$ sheep erythrocytes into erythrocyte rosette-positive $\left(\mathrm{E}^{+}\right)$and -negative $\left(\mathrm{E}^{-}\right)$populations (28). After depleting monocytes by silica (IBL, Fujioka, Japan) or adherence to a plastic surface, $\mathrm{E}^{-}$cells were further enriched for $\mathrm{B}$ cells by positive selection with anti-CD19 mAb-coated immunomagnetic beads (Dynal, Oslo, Norway). Anti-CD19 mAb was subsequently removed by use of Detach a bead (Dynal). $97 \%$ of the cells in the B cell population thus obtained were reactive with anti-CD20 mAbs. $\mathrm{CD}_{19}{ }^{+} \mathrm{IgD}^{+} \mathrm{CD} 27^{-}$and $\mathrm{CD} 19^{+} \mathrm{IgD}^{+} \mathrm{CD} 27^{+} \mathrm{B}$ cells of healthy adults or Patient IN were isolated from the monocyte-depleted $\mathrm{E}^{-}$ cells by sorting using a FACStarTM Plus (Becton Dickinson) under sterile conditions. Both populations thus obtained were $>98 \%$ pure.

Flow cytometric analysis. Peripheral blood MNCs or $\mathrm{E}^{-}$cells were stained with a combination of IgD-FITC, biotin-CD27 followed by streptavidin-PE, and CD20-PerCP. Three color analysis was then performed by FACScan ${ }^{\mathrm{TM}}$ (Becton Dickinson). $\mathrm{E}^{+}$cells were stimulated with PMA (Life Technology, Grand Island, NY) plus ionomycin (Sigma Chemical Co.) for $18 \mathrm{~h}$. After activated $\mathrm{E}^{+}$cells were stained with anti-CD154 mAbs $(5 \mathrm{c} 8,1.7,106)$ or CD40-Fc fusion protein followed by goat anti-Ig-FITC (Southern Biotechnology, Birmingham, AL), single color analysis was carried out.

Preparation of CD70 transfectants and fixation of the transfectants. CD70 transfectants were prepared as previously described (23). The CD70/300-19 and mock/300-19 transfectants were incubated with $1 \%$ paraformaldehyde in PBS for $5 \mathrm{~min}$. After washing with PBS three times, the cells were cultured in RPMI $1640+10 \%$ FCS for $30 \mathrm{~min}$, and used for the analysis.

Immunoglobulin assay by ELISA. MNCs $\left(0.5 \times 10^{6} / \mathrm{ml}\right.$ for $\mathrm{IgG}$, $\operatorname{IgM}$, and $\operatorname{IgA}$, and $10^{6} / \mathrm{ml}$ for $\operatorname{IgE}$ ) or purified peripheral blood B cells were cultured with various stimuli in a volume of $200 \mu \mathrm{l} /$ well for $8 \mathrm{~d}$ for $\mathrm{IgG}, \mathrm{IgM}$, and $\mathrm{IgA}$ assay and 12 to $14 \mathrm{~d}$ for $\mathrm{IgE}$ assay at $37^{\circ} \mathrm{C}$ in a humidified atmosphere with $5 \% \mathrm{CO}_{2}$. In some experiments, MNCs were treated with $2.5 \mu \mathrm{g} / \mathrm{ml}$ of anti-CD70 blocking mAb (HNE51) before the stimulation. The cultured supernatants were harvested and added to goat anti-human Ig (Southern Biotechnology) or anti-IgE (a kind gift from A. Saxon, Division of Clinical Immunology/Allergy, UCLA School of Medicine, Los Angeles, CA), coated 96-well flat ELISA plates with control human IgG, IgM, IgA purchased from Sigma Chemical Co., and IgE from Chemicon International Inc. (Temecula, CA). After an overnight incubation, supernatants were discarded and the wells were washed with $0.05 \%$ Tween-20 in PBS. Bound human Ig was detected with alkaline phosphatase-labeled goat anti-human IgG, IgM, IgA, or IgE (Sigma Chemical Co.) at a dilution of $1 / 2,500$, and color detection was performed. In this ELISA system, no cross-reaction between $\operatorname{IgG}, \operatorname{IgM}, \operatorname{IgA}$, and $\operatorname{IgE}$ occurred. Background readings obtained for wells exposed to PBS in the absence of culture supernatants or control Ig were subtracted.

Reverse transcription-PCR (RT-PCR) of germline C $\epsilon$. Highly purified $\mathrm{CD} 19^{+} \mathrm{IgD}^{+} \mathrm{CD} 27^{+}, \mathrm{CD} 19^{+} \mathrm{IgD}^{+} \mathrm{CD} 27^{-} \mathrm{B}$ cells or whole $\mathrm{B}$ cells at the cell numbers of $10^{6}$ cells were stimulated with or without $100 \mathrm{ng} / \mathrm{ml} \mathrm{IL}-4$ for $16 \mathrm{~h}$. Total RNA was extracted by the single step method (29). First-strand cDNA copies were synthesized using mu-

Table I. Patient Clinical Data, CD154 Expression, and Mutations

\begin{tabular}{|c|c|c|c|c|c|c|c|c|c|c|c|c|}
\hline \multirow[b]{2}{*}{ Cases } & \multirow[b]{2}{*}{ Age/sex } & \multicolumn{4}{|c|}{ Serum immunoglobulin levels } & \multicolumn{4}{|c|}{ CD154 expression } & \multicolumn{2}{|c|}{ Mutation of CD154 } & \multirow{2}{*}{$\begin{array}{c}\text { Current } \\
\gamma \text {-globulin } \\
\text { therapy }\end{array}$} \\
\hline & & $\underset{(\mathrm{mg} / \mathrm{dl})}{\mathrm{IgG}}$ & $\underset{(\mathrm{mg} / \mathrm{dl})}{\mathrm{IgM}}$ & $\underset{(\mathrm{mg} / \mathrm{dl})}{\mathrm{IgA}}$ & $\begin{array}{c}\mathrm{IgE} \\
(\mathrm{IU} / \mathrm{ml})\end{array}$ & $\mathrm{CD} 40-\mathrm{Fc}$ & $5 \mathrm{c} 8$ & 1.7 & 106 & Nucleotide change & Consequence & \\
\hline Pt. IN & $24 \mathrm{yr} / \mathrm{M}$ & 40 & 1100 & $<5$ & $<10$ & 2.6 & 0.4 & 0.9 & 3.3 & $\mathrm{C} 782 \rightarrow \mathrm{T}$ & Thr $254 \rightarrow$ Met & - \\
\hline Pt. YF & $\begin{array}{l}23 \mathrm{yr} / \mathrm{M} \\
(6 \mathrm{yr})^{*}\end{array}$ & $\begin{array}{l}647 \\
(13)\end{array}$ & $\begin{array}{c}293 \\
(424)\end{array}$ & $\begin{array}{l}215 \\
(74)\end{array}$ & $\begin{array}{l}<10 \\
(<10)\end{array}$ & 1.3 & ND & ND & 1.9 & $\begin{array}{l}\text { 178-309 deletion } \\
\text { (Exon-2 skipping) } \\
\text { 19-bp insertion }\end{array}$ & Stop at 101 & + \\
\hline Pt. TF & $\begin{array}{l}16 \mathrm{yr} / \mathrm{M} \\
(1 \mathrm{yr} 6 \mathrm{~m})\end{array}$ & $\begin{array}{l}654 \\
(47)\end{array}$ & $\begin{array}{l}1390 \\
(330)\end{array}$ & $\begin{array}{l}106 \\
(23)\end{array}$ & $\begin{array}{l}<10 \\
(<10)\end{array}$ & 1.7 & ND & ND & 1.8 & $\begin{array}{l}\text { 178-309 deletion } \\
\text { (Exon-2 skipping) } \\
\text { 19-bp insertion }\end{array}$ & $\begin{array}{l}\text { 59-96 deletion } \\
\text { Stop at } 101\end{array}$ & + \\
\hline Pt. TY & $\begin{array}{l}12 \mathrm{yr} / \mathrm{M} \\
(8 \mathrm{yr})\end{array}$ & $\begin{array}{l}365 \\
(26)\end{array}$ & $\begin{array}{c}358 \\
(153)\end{array}$ & $\begin{array}{c}44 \\
(<5)\end{array}$ & $\begin{array}{l}<10 \\
(<10)\end{array}$ & 1.0 & ND & ND & 0.9 & $\mathrm{~T} 713 \rightarrow \mathrm{C}$ & Leu $231 \rightarrow$ Ser & + \\
\hline Pt. AY & $\begin{array}{l}6 \mathrm{yr} / \mathrm{M} \\
(3 \mathrm{mon})\end{array}$ & $\begin{array}{l}433 \\
(234)\end{array}$ & $\begin{array}{c}80 \\
(31)\end{array}$ & $\begin{array}{c}5 \\
(<5)\end{array}$ & $\begin{array}{l}<10 \\
(\mathrm{ND})\end{array}$ & 0.9 & ND & ND & 0.9 & $\mathrm{~T} 713 \rightarrow \mathrm{C}$ & Leu $231 \rightarrow$ Ser & + \\
\hline Pt. RM & $\begin{array}{l}13 \mathrm{yr} / \mathrm{M} \\
(3 \mathrm{yr})\end{array}$ & $\begin{array}{c}490 \\
(290)\end{array}$ & $\begin{array}{c}410 \\
(120)\end{array}$ & $\begin{array}{l}<5 \\
(<5)\end{array}$ & $\begin{array}{l}<10 \\
(\mathrm{ND})\end{array}$ & 1.8 & ND & ND & 0.9 & $\mathrm{~T} 128 \rightarrow \mathrm{G}$ & Met $36 \rightarrow$ Arg & + \\
\hline Cont. & $30 \mathrm{yr} / \mathrm{M}$ & & & & & 68.5 & 72.4 & 75.6 & 71 & & & \\
\hline
\end{tabular}

*Parentheses show ages and serum immunoglobulin levels at the time of diagnosis before $\gamma$-globulin replacement therapy. 
rine Moloney leukemia virus reverse transcriptase (GIBCO BRL, Grand Island, NY) with oligo (dT) (GIBCO BRL) as a primer in a total volume of $20 \mu \mathrm{l}$. PCR was then performed with C€ exon sense primer 5'-CATGCGGTCCACGACCAAGAC-3' and antisense primer 5'-CCACTGCACAGCTGGATGGAG-3'. $2 \mu \mathrm{l}$ of cDNA were amplified in PCR using each primer and Taq DNA polymerase (GIBCO $\mathrm{BRL}$ ). The amplified products were analyzed on a $1.2 \%$ agarose gel containing ethidium bromide and visualized by ultraviolet light illumination. $\beta_{2}$-microglobulin sense primer $5^{\prime}$-GCTATGTGTCTGGGTTTCAT-3' and antisense primer 5'-CCCACTTAACTATCTTGGGC-3' were used as controls (30).

\section{Results}

CD154 expression and mutations in XHIM patients. Upon stimulation by PMA plus ionomycin, T cells obtained from all of the six patients with XHIM demonstrated no CD154 expression as determined by flow cytometric analysis using several mAbs specific for CD154 and CD40-Fc fusion protein (Table I). In contrast, T cell activation was associated with marked increases in the CD69 surface expression (data not shown). Approximately $70 \%$ of activated $\mathrm{T}$ cells obtained from healthy controls expressed CD154 on the surface after stimulation by PMA plus ionomycin (Table I).

Detailed sequence analysis of cDNA obtained from the six patients was previously described (26). Briefly, Patients TY and AY, who are siblings, revealed the same point mutation at nucleotide $\mathrm{T} 713$ to $\mathrm{C}$, resulting in a change of leucine 231 to serine. Patient IN had a point mutation at nucleotide $\mathrm{C} 782$ to $\mathrm{T}$, changing from threonine 254 to methionine, and Patient $\mathrm{RM}$ at nucleotide $\mathrm{T} 128$ to $\mathrm{G}$, resulting in amino acid change in transmembrane domain from methionine 36 to arginine. Two of the siblings (Patients YF and TF) had the same unique mutations within introns, resulting in alternative splicing. They had a single-point mutation at a splice site of intron 2 and subsequently had two different sizes of cDNA, demonstrating skipping of the entire exon 2 or the insertion of 19 nucleotides (Table I).

Immunoglobulin secretion from patients' MNCs. The ability of XHIM B cells to secrete immunoglobulins was assessed by stimulation with SAC plus IL-2, anti-CD40 plus IL-10, or IL-10 plus IL-2. Upon stimulation with three types of the combination, MNCs obtained from healthy volunteers produced $\mathrm{IgG}, \mathrm{IgM}$, and IgA normally (Table II). In other experiments with normal MNCs or purified B cells, anti-CD40 or IL-2 alone did not induce immunoglobulin secretion, whereas SAC or IL-10 alone induced low levels of immunoglobulin secretion (data not shown)(23). In contrast to the results obtained from normal MNCs, in all but two of the XHIM patients, IgA and IgG secretion was below detection to marginal levels. Adequate IgG production was found in Patients YF and TF when MNCs of the patients were stimulated with SAC plus IL-2, anti-CD40 plus IL-10, or IL-10 plus IL-2. On the other hand, IgM production in all of the six patients was moderate to the same as that of healthy controls (Table II). When MNCs were treated with anti-CD70-blocking $\mathrm{mAb}$ and cultured in the presence of SAC plus IL-2, the IgG production was reduced by $32 \pm 7 \%($ mean $\pm \mathrm{SD}, n=5)$ in controls and only $3 \%$ in Patient IN and $4 \%$ in Patient TY.

The stimulation with SAC plus anti-CD40 plus IL-10 was reported to induce maximum immunoglobulin secretion in XHIM (31). In disagreement with the data, Saiki et al. (32) reported that there was no induction of $\operatorname{IgG}$ and $\operatorname{IgA}$ secretion in
Table II. Immunoglobulin Production by XHIM Patient MNC after Various Stimuli*

\begin{tabular}{|c|c|c|c|c|}
\hline Donor Ig class & $\mathrm{SAC}^{\ddagger}+\mathrm{IL}-2^{\ddagger}$ & $\begin{array}{c}\text { Anti-CD } 40^{\ddagger} \\
+ \text { IL-10 }\end{array}$ & IL-10+IL-2 & $\begin{array}{l}\text { SAC+IL-2+IL-10 } \\
+ \text { anti-CD } 40\end{array}$ \\
\hline Pt. IN IgA ${ }^{\S}$ & $<64$ & $<64$ & $<64$ & $<64$ \\
\hline $\operatorname{IgM}^{\S}$ & $768 \pm 27$ & $544 \pm 21$ & $450 \pm 42$ & $2510 \pm 738$ \\
\hline $\mathrm{IgG}^{\S}$ & $670 \pm 41$ & $546 \pm 39$ & $234 \pm 25$ & $2888 \pm 280$ \\
\hline Cont. IgA & $3283 \pm 973$ & $890 \pm 78$ & $811 \pm 113$ & $1168 \pm 119$ \\
\hline IgM & $1241 \pm 837$ & $249 \pm 11$ & $241 \pm 17$ & $257 \pm 28$ \\
\hline IgG & $8499 \pm 1371$ & $4424 \pm 1397$ & $3997 \pm 746$ & $6977 \pm 1358$ \\
\hline Pt. TF IgA & $<64$ & $<64$ & $<64$ & 119 \\
\hline $\operatorname{IgM}$ & $2129 \pm 434$ & $1900 \pm 318$ & $1677 \pm 578$ & $2210 \pm 798$ \\
\hline $\mathrm{IgG}$ & $2378 \pm 222$ & $1659 \pm 213$ & $1053 \pm 130$ & $3746 \pm 1135$ \\
\hline Pt. YF IgA & $<64$ & $89 \pm 2$ & $<64$ & $<64$ \\
\hline $\operatorname{IgM}$ & $1609 \pm 247$ & $235 \pm 70$ & $94 \pm 8$ & $2119 \pm 473$ \\
\hline $\operatorname{IgG}$ & $3012 \pm 1454$ & $794 \pm 214$ & $612 \pm 79$ & $2890 \pm 659$ \\
\hline Cont. IgA & $3054 \pm 1024$ & $683 \pm 42$ & $345 \pm 19$ & $3832 \pm 824$ \\
\hline $\operatorname{IgM}$ & $3509 \pm 279$ & $511 \pm 133$ & $117 \pm 25$ & $3009 \pm 245$ \\
\hline $\mathrm{IgG}$ & $6732 \pm 1825$ & $3017 \pm 593$ & $2403 \pm 771$ & $5997 \pm 1432$ \\
\hline Pt. TY IgA & $<64$ & $<64$ & $<64$ & $<64$ \\
\hline $\operatorname{IgM}$ & $1182 \pm 298$ & $476 \pm 112$ & $477 \pm 105$ & $556 \pm 186$ \\
\hline $\mathrm{IgG}$ & $785 \pm 137$ & $<125$ & $<125$ & $1800 \pm 246$ \\
\hline Pt. AY IgA & $<64$ & $<64$ & $<64$ & $<64$ \\
\hline IgM & $1001 \pm 60$ & $907 \pm 157$ & $1087 \pm 72$ & $1033 \pm 241$ \\
\hline $\mathrm{IgG}$ & $<125$ & $<125$ & $<125$ & $2013 \pm 119$ \\
\hline Cont. IgA & $7402 \pm 1957$ & $5715 \pm 1239$ & $582 \pm 1652$ & $>10000$ \\
\hline $\operatorname{IgM}$ & $7185 \pm 1427$ & $2756 \pm 279$ & $2832 \pm 110$ & $8470 \pm 2438$ \\
\hline $\operatorname{IgG}$ & $9821 \pm 2153$ & $6370 \pm 1413$ & $5240 \pm 1257$ & $>10000$ \\
\hline Pt. RM IgA & $<64$ & $<64$ & $<64$ & $<64$ \\
\hline $\operatorname{IgM}$ & $789 \pm 168$ & $675 \pm 98$ & $578 \pm 43$ & $2908 \pm 463$ \\
\hline $\mathrm{IgG}$ & $<125$ & $<125$ & $<125$ & $1751 \pm 367$ \\
\hline Cont. IgA & $6341 \pm 987$ & $3177 \pm 652$ & $1009 \pm 610$ & $3177 \pm 834$ \\
\hline $\operatorname{IgM}$ & $6579 \pm 1043$ & $2356 \pm 590$ & $820 \pm 52$ & $6357 \pm 1436$ \\
\hline $\operatorname{IgG}$ & $>10000$ & $6549 \pm 1786$ & $7390 \pm 1595$ & $>10000$ \\
\hline
\end{tabular}

*MNCs $\left(10^{5} /\right.$ well) were used in this study. ${ }^{\ddagger}$ Final concentrations of SAC, IL-2, anti-CD40, and IL-10 were $0.01 \%, 50 \mathrm{U} / \mathrm{ml}, 1 \mu \mathrm{g} / \mathrm{ml}$, and $50 \mathrm{ng} / \mathrm{ml}$, respectively. ${ }^{\S}$ All immunoglobulin concentrations are given in $\mathrm{ng} / \mathrm{ml}$.

four XHIM patients. In four of our patients (Patient IN, TY, AY, and RM), marginal levels of $\operatorname{IgG}$ secretion, but no $\operatorname{IgA}$, were observed after the stimulation. Interestingly, costimulation of patients' MNCs with SAC plus IL-2 plus anti-CD40 plus IL-10 induced secretion of large amounts of IgG and IgM, but not $\operatorname{Ig}$ A. These data demonstrate that, although there is a variation in the immunoglobulin production, B cells of XHIM patients produce no to marginal levels of $\mathrm{IgG}$ and $\mathrm{IgA}$ production, but adequate levels of $\operatorname{IgM}$, and the cells have ability to induce large amounts of $\mathrm{IgG}$ and $\mathrm{IgM}$ secretion by triggering via immunoglobulin receptors and CD40 in cooperation with IL-2 and IL-10.

The defect of $\mathrm{IgD} \mathrm{D}^{-} \mathrm{CD} 27^{+} \mathrm{B}$ cells in patients with XHIM. The blockage of CD40/CD154 interaction leads to impairment of germinal center formation and development of immunological B cell memory $(33,34)$. The observation prompted us to investigate the function of peripheral blood B cells in XHIM patients. Experiments were therefore conducted in which phenotypic analysis of their peripheral blood B cells was performed. As previously reported (23), adult peripheral blood B cells could be subdivided into three discrete subtypes by the 


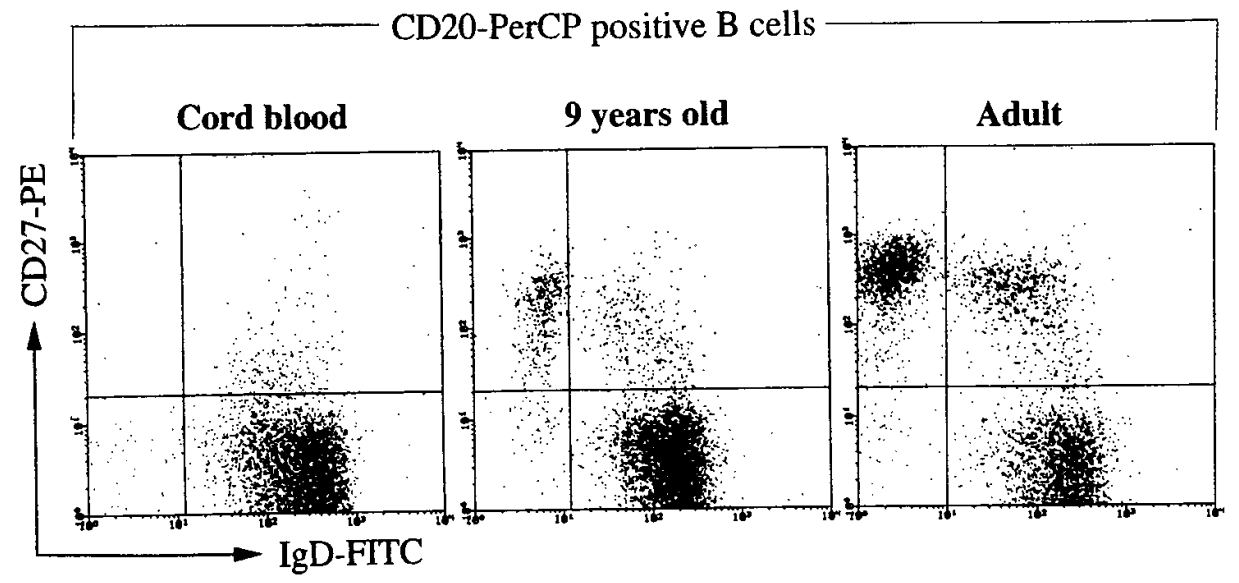

B
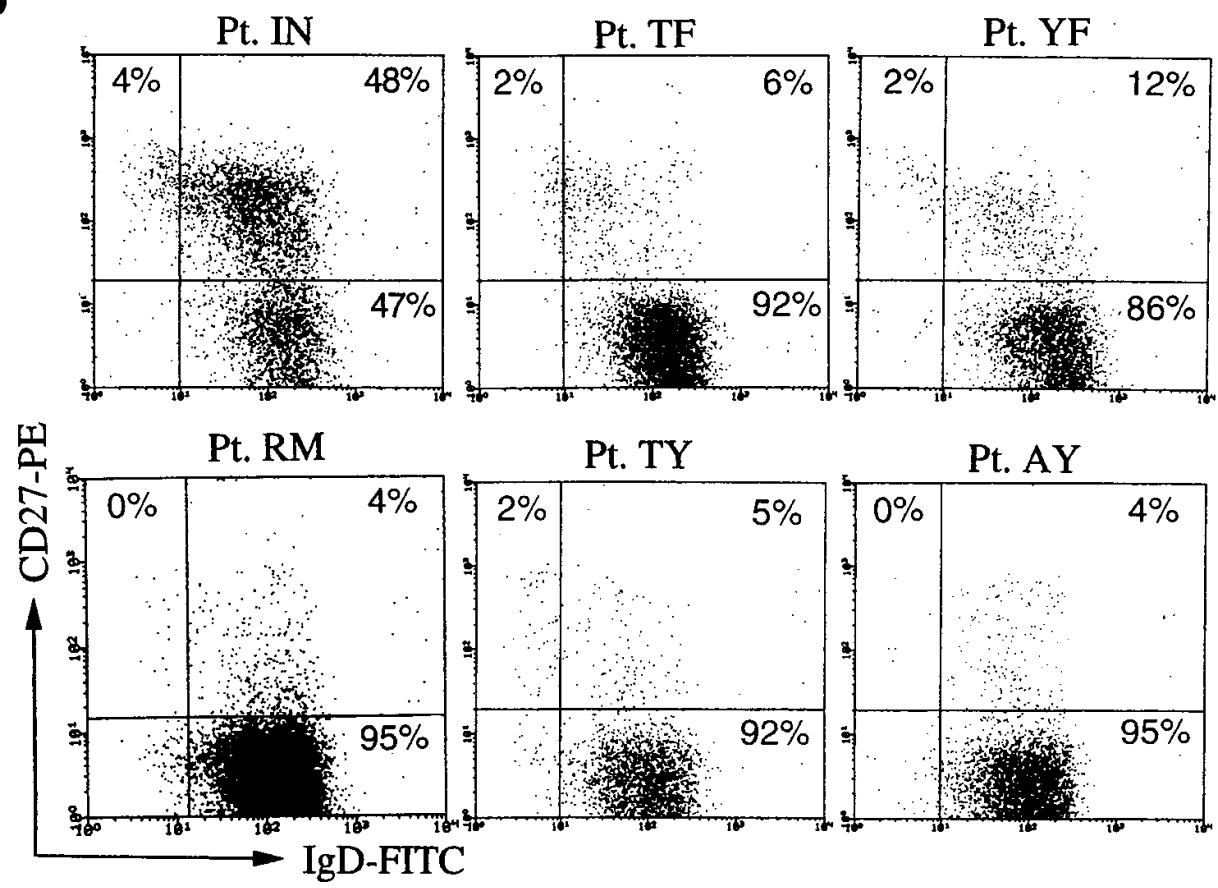

Figure 1. B cell subpopulations and defect of $\mathrm{IgD}^{-} \mathrm{CD} 27^{+}$memory B cells in XHIM patients. MNCs of cord blood and peripheral blood of children aged $9 \mathrm{yr}$ and of adult $(A)$ or MNCs obtained from six XHIM patients $(B)$ were stained with anti-IgDFITC, anti-CD27-biotin followed by avidin-PE, and anti-CD20PerCP. Three color analysis was carried out by gating CD20PerCP positive B cells. Data were displayed as density plots with green (FITC) fluorescence, $\mathrm{IgD}$, on the $\mathrm{x}$-axis, and orange $(P E)$ fluorescence, CD27, on the $\mathrm{y}$-axis by the log scale. These data were representative of 15 cord blood samples, and peripheral blood samples of five 9-yrold children and 20 adults. The percentage of positive cells is indicated.
IgD and CD27 expression, whereas cord blood B cells chiefly consisted of $\mathrm{CD}^{-} 7^{-}$naive $\mathrm{B}$ cells and the $\mathrm{CD} 27$ expression on $\mathrm{B}$ cells increased with age (Fig. $1 A$ ).

Three color flow cytometric analysis of peripheral blood cells in the XHIM patients revealed that the number of $\mathrm{IgD}^{-}$ $\mathrm{CD} 27^{+} \mathrm{B}$ cells was greatly decreased in all the patients as compared to that of normal volunteers (Fig. $1 B$ ), implying that a generation of cells with the surface phenotype of memory B cells was diminished in the XHIM patients. Percentages of $\mathrm{IgD}^{+} \mathrm{CD} 27^{+} \mathrm{B}$ cells were within normal levels, whereas percentages of $\mathrm{IgD}^{+} \mathrm{CD} 27^{+} \mathrm{B}$ cells in Patient IN were increased, compared with those of normal adults (Fig. $1 B$ ) (23). These data illustrate that peripheral blood $\mathrm{B}$ cell populations separated by the expressions of $\operatorname{IgD}$ and CD27 in XHIM patients are composed differently, supporting a view that an impaired germinal center formation due to defective CD154 expression results in impaired development of $\mathrm{IgD}^{-} \mathrm{CD} 27^{+}$memory $\mathrm{B}$ cells.

Production of IgM from IgD ${ }^{+} \mathrm{CD}_{27^{+}} \mathrm{B}$ cells in XHIM patient. A previous study has demonstrated that $\mathrm{IgD}^{-} \mathrm{CD} 27^{+} \mathrm{B}$ cells produce $\mathrm{IgG}, \mathrm{IgM}$, and $\mathrm{IgA}$, and that $\mathrm{IgD}^{+} \mathrm{CD} 27^{+} \mathrm{B}$ cells predominantly produce $\operatorname{IgM}(23)$. Therefore, one may postulate that the $\mathrm{IgD}^{+} \mathrm{CD} 27^{+} \mathrm{B}$ cell population in XHIM patients could produce IgM but little amounts of IgG and IgA. To explore this possibility, further experiments were carried out to examine whether the patient B cell populations separated by the expression of $\operatorname{IgD}$ and $\mathrm{CD} 27$ have different functions. We separated $\mathrm{IgD}^{+} \mathrm{CD} 27^{+} \mathrm{B}$ cells of Patient IN (Fig. $2 \mathrm{~A}$ ) and in- 

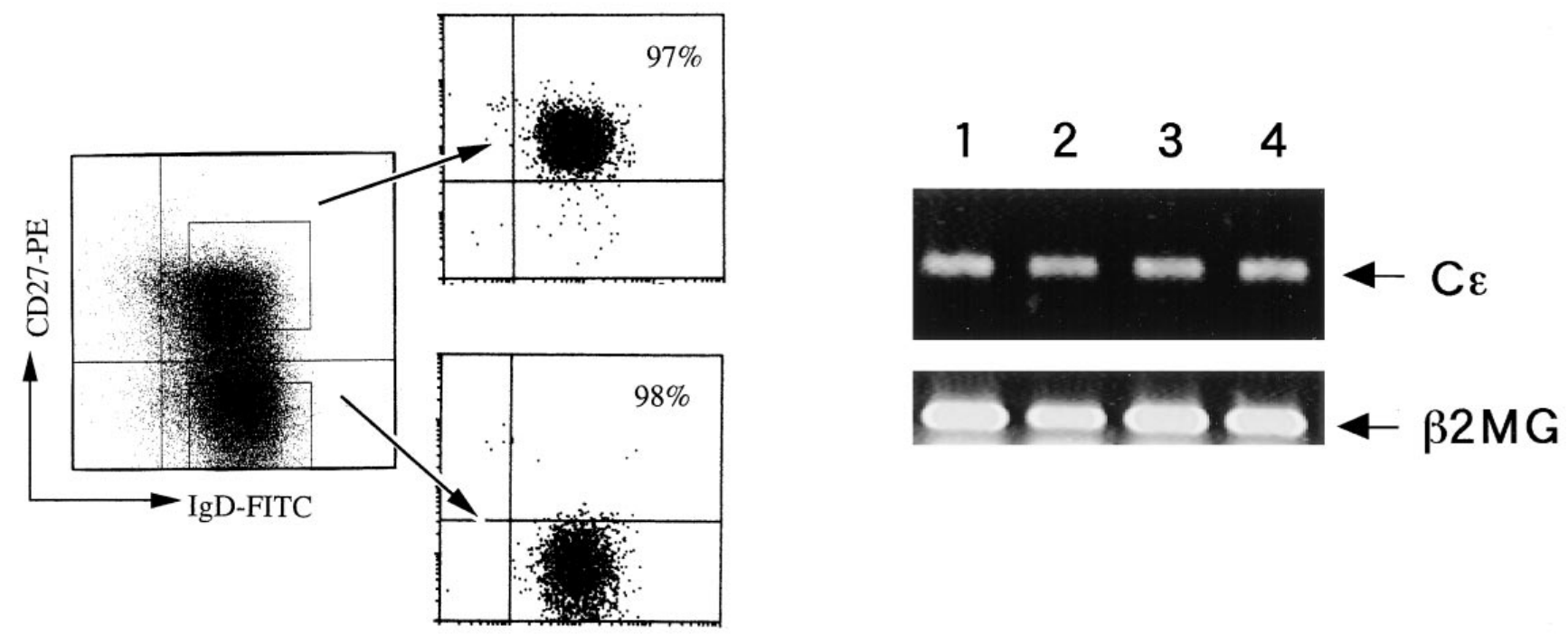

Figure 2. Purification of $\mathrm{IgD}^{+} \mathrm{CD} 27^{+}$and $\mathrm{IgD}{ }^{+} \mathrm{CD} 27^{-} \mathrm{B}$ cell populations from the patient and germline $\epsilon$ transcripts. $(A) \mathrm{MNCs}$ obtained from Patient IN were stained with anti-IgD-FITC, biotin-labeled anti-CD27 followed by streptavidin-PE and anti-CD19-APC. IgD ${ }^{+} \mathrm{CD} 27^{+}$and $\mathrm{IgD}^{+} \mathrm{CD} 27^{-} \mathrm{B}$ cells were then purified by FACStarTM Plus. Purity is indicated as the percentage. $(B)$ The highly purified IgD ${ }^{+} \mathrm{CD}^{\mathrm{T}} 7^{+} \mathrm{B}$ cells (lanes 1 and 3) and $\mathrm{IgD}^{+} \mathrm{CD} 27^{-}$B cells (lanes 2 and 4 ) were stimulated with $100 \mathrm{ng} / \mathrm{ml} \mathrm{IL-4} \mathrm{(lanes} 1$ and 2 ) or IL-4 plus $1 \mu \mathrm{g} / \mathrm{ml}$ anti-CD40 (lanes 3 and 4$)$ for $16 \mathrm{~h}$. After extraction of total RNA, RT-PCR was performed with C€ exon sense and antisense primers. $\beta_{2}$-microglobulin $\left(\beta_{2 \mathrm{MG}}\right)$ was used as a positive control.

vestigated the immunoglobulin production in various $\mathrm{B}$ cell activation systems. $\mathrm{IgD}^{+} \mathrm{CD} 27^{+} \mathrm{B}$ cells obtained from normal adults by sorting produced significant levels of IgM and moderate levels of IgG in the presence of SAC plus IL-2 or antiCD40 plus IL-10, but no detectable levels of $\lg \mathrm{A}$. In contrast, $\mathrm{IgD}^{+} \mathrm{CD} 27^{+} \mathrm{B}$ cells obtained from Patient IN produced moderate levels of $\operatorname{IgM}$, mild $\mathrm{IgG}$, and no $\mathrm{IgA}$ in the presence of SAC plus IL-2 or anti-CD40 plus IL-10 (Fig. 3). As for CD27naive $\mathrm{B}$ cells, the cells of Patient IN, as well as healthy controls, could not produce $\operatorname{IgG}, \operatorname{IgM}$, and $\operatorname{IgA}$ in the presence of SAC plus IL-2 or anti-CD40 plus IL-10 (Fig. 3). Addition of CD70 transfectants to $\mathrm{IgD}^{+} \mathrm{CD} 27^{+} \mathrm{B}$ cells in the presence of SAC plus IL-2 or anti-CD40 plus IL-10 augmented the IgG and IgM production by about twofold as compared to that of mock transfectants (data not shown). Very interestingly, the stimulation with SAC plus IL-2 plus anti-CD40 plus IL-10 promoted the production of $\mathrm{IgG}$ and $\mathrm{IgM}$ from $\mathrm{IgD}^{+} \mathrm{CD} 27^{+} \mathrm{B}$ cells of both Patient IN and healthy controls. IgG and IgM production were also found in $\mathrm{IgD}^{+} \mathrm{CD} 27^{-} \mathrm{B}$ cells by the stimulation. However, no IgA production was recognized from two of the B cell populations by the stimuli.

Having shown the difference in $\operatorname{IgA}$, IgM, and IgG synthesis between $\mathrm{IgD}^{+} \mathrm{CD} 27^{+}$and $\mathrm{IgD}^{+} \mathrm{CD} 27^{-} \mathrm{B}$ cells, we also examined the germline $\epsilon$ transcripts in two of the populations by RT-PCR. Germline $\mathrm{C} \epsilon$ gene transcription was not found in unstimulated whole B cells obtained from healthy volunteers (data not shown). In the presence of IL-4 or IL-4 plus anti$\mathrm{CD} 40$, both $\mathrm{IgD}^{+} \mathrm{CD} 27^{+}$and $\mathrm{IgD}^{+} \mathrm{CD} 27^{-} \mathrm{B}$ cell populations obtained from Patient IN equally expressed germline $\epsilon$ mRNA (Fig. 2 B). Similar results of germline $\epsilon$ gene transcripts were obtained when purified $\mathrm{IgD}^{+} \mathrm{CD} 27^{+}$and $\mathrm{IgD}^{+} \mathrm{CD} 27^{-} \mathrm{B}$ cells from healthy controls were stimulated with IL-4 or IL-4 plus anti-CD40 (data not shown).
Immunoglobulin production from cord blood B cells. A majority of cord blood B cells were composed of $\mathrm{IgD}^{+} \mathrm{CD} 27^{-} \mathrm{B}$ cells; $\mathrm{IgD}^{+} \mathrm{CD} 27^{+} \mathrm{B}$ cells constituted a small population of $\mathrm{B}$ cells (Fig. $1 A$ ). Highly purified cord blood B cells by positive selection with CD19 beads showed defective IgG and IgA secretion by the stimulation with SAC plus IL-2, anti-CD40 plus IL-10, or IL-10 plus IL-2. On the other hand, only low levels of IgM were observed after the addition of SAC plus IL-2 or antiCD40 plus IL-10. Significant induction of IgG and IgM, but not IgA, was observed after the stimulation with SAC plus IL-2 plus anti-CD40 plus IL-10 (Table III). These data indicate that the composition of cord blood B cells separated by $\operatorname{IgD}$ and CD27 is in accordance with that of XHIM patient B cells, and that the pattern of $\mathrm{IgG}$ and $\mathrm{IgA}$ secretion from highly purified cord blood B cells is similar to that of XHIM patient B cells and that of $\mathrm{IgD}^{+} \mathrm{CD} 27^{-} \mathrm{B}$ cells obtained from normal adults.

IgE production. Anti-CD40 plus IL-4 was reported to induce class switching from IgM to IgE in XHIM patients (3, 4, $31,35,36)$. IgE production was examined by ELISA. In healthy controls, the stimulated MNCs with IL-4 plus antiCD40, but not IL-4 alone, resulted in IgE secretion. The levels of IgE measured in the cultures varied among the patients. Three of the patients (Patients YF, TF, and RM) could produce $\operatorname{IgE}$ at the same levels as did healthy controls in the presence of IL-4 plus anti-CD40. Adequate IgE secretion was not detected in the other three patients. However, it is interesting to note that, in accordance with the results by Saiki et al. (32), the addition of IL-10 to anti-CD40 plus IL-4 resulted in measurable levels of IgE synthesis in Patient IN (Table IV). These data suggest that, although B cells of XHIM patients are composed of only $\mathrm{IgD}^{+} \mathrm{CD} 27^{+}$and $\mathrm{IgD}^{+} \mathrm{CD} 27^{-}$cells, the $\mathrm{B}$ cells have ability to produce $\mathrm{IgE}$ via $\mathrm{CD} 40$ signaling in cooperation with IL-4 and IL-10. 


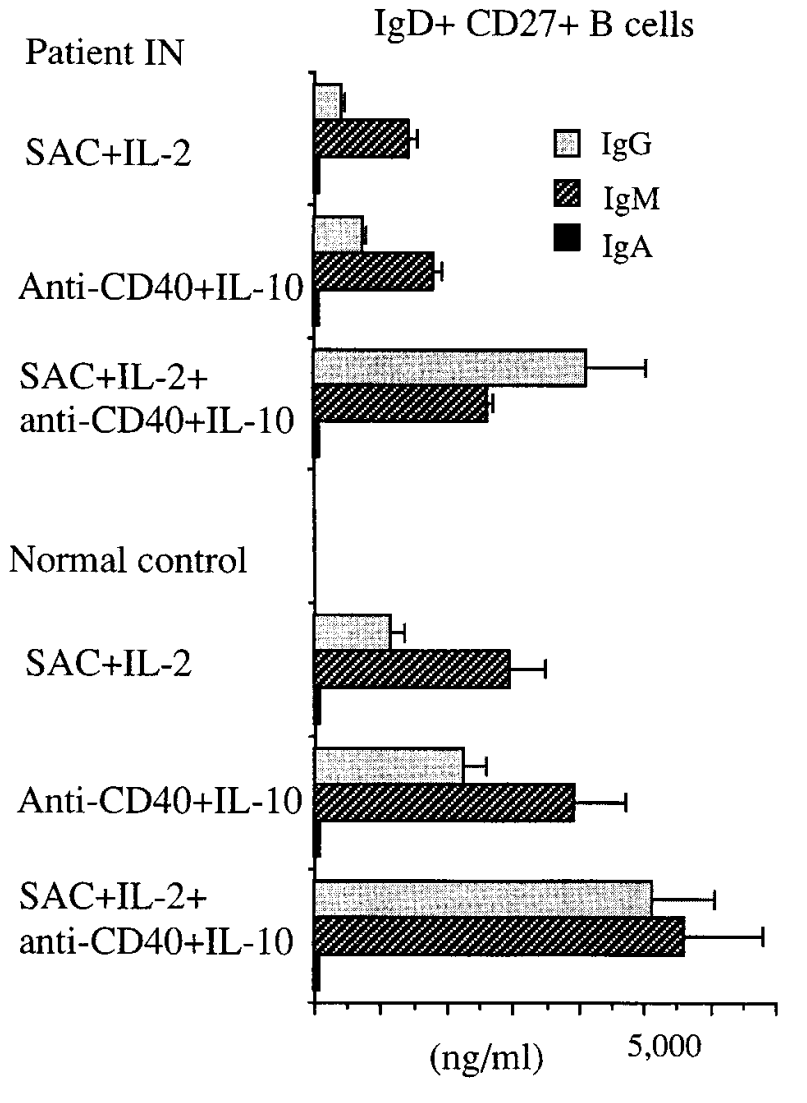

\section{Discussion}

Germinal centers in the lymph node and spleen are sites of somatic mutation and affinity maturation of B cells. Though the molecular events required to drive proliferation, differentiation, and memory B cell formation in the germinal center are not completely understood, evidence from CD40/CD154 interaction and XHIM patients suggests that CD40 plays a major role in these events $(1,13,33)$. For example, mice treated with an antibody to CD154 are incapable of germinal center formation, and are unable to produce memory B cells (37). CD154deficient mice generated by gene-targeted disruption do not develop germinal centers in response to antigens, suggesting inability to develop memory B cell responses (9). These findings prompted us to examine whether memory B cells defined

Table III. Immunoglobulin Production by Purified Cord Blood B Cells*

\begin{tabular}{lccc}
\hline & $\begin{array}{c}\mathrm{IgG} \\
(\mathrm{ng} / \mathrm{ml})\end{array}$ & $\begin{array}{c}\mathrm{IgM} \\
(\mathrm{ng} / \mathrm{ml})\end{array}$ & $\begin{array}{c}\mathrm{IgA} \\
(\mathrm{ng} / \mathrm{ml})\end{array}$ \\
\hline $\mathrm{SAC}^{\ddagger}+\mathrm{IL}^{\ddagger}{ }^{\ddagger}$ & $<125$ & $596 \pm 168$ & $<64$ \\
$\mathrm{CD}^{\ddagger}+\mathrm{IL}-10^{\ddagger}$ & $<125$ & $378 \pm 96$ & $<64$ \\
$\mathrm{IL}-2+\mathrm{IL}-10$ & $<125$ & $<96$ & $<64$ \\
$\mathrm{SAC}+\mathrm{IL}-2+\mathrm{CD} 40+\mathrm{IL}-10$ & $6860 \pm 1370$ & $6452 \pm 987$ & $<64$
\end{tabular}

*Highly purified B cells $\left(2.5 \times 10^{4} /\right.$ well $)$ were used in this study. *Final concentrations of SAC, IL-2, anti-CD40, and IL-10 were $0.01 \%, 50 \mathrm{U} / \mathrm{ml}$, $1 \mu \mathrm{g} / \mathrm{ml}$, and $50 \mathrm{ng} / \mathrm{ml}$, respectively.
$\operatorname{IgD}+\mathrm{CD} 27-\mathrm{B}$ cells

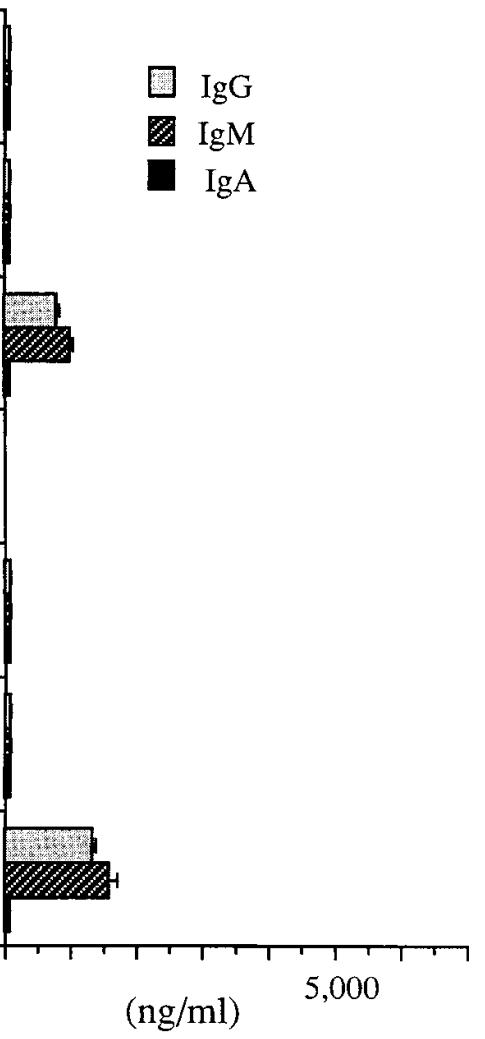

Figure 3. Immunoglobulin production by $\operatorname{IgD}{ }^{+} \mathrm{CD} 27^{+}$and $\mathrm{IgD}^{+} \mathrm{CD} 27^{-} \mathrm{B}$ cells. Purified B cells $\left(2.5 \times 10^{4} /\right.$ well $)$ of Patient IN (Fig. $2 A$ ) and normal adults were cultured in indicated $B$ cell stimulation systems. After $8 \mathrm{~d}$ of culture, immunoglobulin levels in the supernatants were assayed by ELISA, as described in Methods. by CD27 molecule in the peripheral blood of XHIM patients were present, which may provide evidence for the lack of memory B cells as a cause of the impaired immunoglobulin production in vivo and in vitro in XHIM.

Based on the published reports, hyper-IgM syndrome can be classified into two types due to CD40 abnormalities and mutations in CD154 $(37,38)$. To clarify B cell functions in XHIM patients due to CD154 gene defects but not CD40 signal abnormality in CD40 pathway, we enrolled the patients with mutations in CD154. These mutations were confirmed by flow cytometric analysis using anti-CD40 mAbs and CD40-Fc

Table IV. IgE Secretion in XHIM Patients*

\begin{tabular}{lccc}
\hline & IL-4 $^{\ddagger}$ & IL-4+anti-CD40 & IL-4+anti-CD40+IL-10 \\
\hline Pt. IN & $<5^{\S}$ & $<5$ & $11.3 \pm 2.1$ \\
Control & $<5$ & $26.2 \pm 11.8$ & $71.3 \pm 21.8$ \\
Pt. TF & $<5$ & $19.3 \pm 5.0$ & ND \\
Pt. YF & $<5$ & $36.1 \pm 13.2$ & ND \\
Control & $<5$ & $42.9 \pm 17.2$ & ND \\
Pt. AY & $<5$ & $7.8 \pm 4.3$ & ND \\
Pt. TY & $<5$ & $6.9 \pm 3.5$ & ND \\
Control & $<5$ & $21.0 \pm 6.8$ & ND \\
Pt. RM & $<5$ & $15.1 \pm 6.1$ & $96.0 \pm 18.4$ \\
Control & $<5$ & $20.4 \pm 9.7$ & $129.4 \pm 34.5$ \\
& & &
\end{tabular}

* MNCs $\left(10^{5} /\right.$ well $)$ were used in this study. ${ }^{*}$ Final concentrations of IL-4, anti-CD40, and IL-10 were $50 \mathrm{ng} / \mathrm{ml}, 1 \mu \mathrm{g} / \mathrm{ml}$, and $100 \mathrm{ng} / \mathrm{ml}$, respectively. ${ }^{8}$ Immunoglobulin E concentration is given in $\mathrm{ng} / \mathrm{ml}$. 
fusion protein as well as sequencing of CD154 gene. In addition, because CD27 expression on B cells increases with age (23), we selected older patients with XHIM in Japan.

Several reports indicate that the patient $\mathrm{B}$ cells have ability to produce $\mathrm{IgG}, \mathrm{IgA}$, or IgE in the presence of anti-CD40 plus cytokines $(3,31,32,36,39)$. On the other hand, it is reported that apparent $\mathrm{IgG}$ and $\mathrm{IgA}$ production is not observed with anti-CD40 plus IL-10 (32). In our cases, B cells from some but not all of our XHIM patients did not secrete $\mathrm{IgG}$ in response to anti-CD40 plus IL-10 or SAC plus IL-2, which is similar to the reported findings of several XHIM patients $(32,40)$. However, in disagreement with the XHIM patients reported (35), IgA secretion was absent in all our patients regardless of the B cell stimulation systems (Table II). The reasons for the discrepancies of $\operatorname{IgA}$, IgM, and $\mathrm{IgG}$ production among published data and the present study are not clear. One possibility is that there exists variations in the patient population due to different mutations in CD154 gene and that ability to produce immunoglobulins gradually changes with age. Alternatively, the sensitivity of ELISAs for detecting immunoglobulins may vary in laboratories. Very interestingly, IgG and IgM, but not IgA, was dramatically increased in cultures of XHIM B cells upon addition of anti-CD40 plus IL-10 plus IL-2 plus SAC. These results are similar to the findings of $\operatorname{IgG}, \operatorname{IgM}$, and $\mathrm{IgA}$ secretion by cord blood $\mathrm{B}$ cells and adult $\mathrm{IgD}^{+} \mathrm{CD} 27^{-} \mathrm{B}$ cells. $\mathrm{IgD}^{+} \mathrm{CD} 27^{-}$naive $\mathrm{B}$ cells have ability to produce, at least, $\mathrm{IgG}$ and $\operatorname{IgM}$, in response to signaling via immunoglobulin receptors and CD40 in cooperation of cytokines such as IL-10 and IL-2 in vitro.

Activation with anti-CD40 or CD154 molecule is shown to induce proliferation in XHIM B cells $(3,4)$, indicating that the $\mathrm{B}$ cell function in XHIM patients may be normal. However, one important issue that has not been clearly addressed in studies of XHIM is the mechanism underlying the inability to produce adequate levels of $\mathrm{IgG}$ and $\mathrm{IgA}$ in response to various stimuli including stimulation via CD40 in vitro. Gray et al. (13) demonstrated that the development of memory B cell populations measured by adoptive transfer was grossly impaired by administration of soluble CD40 fusion protein, so as to block the CD40/CD154 interaction. They also indicated that by the blockage antigen-specific IgG responses were grossly inhibited, whereas the IgM response was augmented greatly, suggesting that there is a CD40 ligand-independent pathway of B cell activation that leads to IgM response.

It is generally admitted that cord blood and neonate B cells produce very low levels of immunoglobulin, presumably because of $\mathrm{T}$ cell immaturity and poor helper activity, including the undetectable CD154 expression on T cells $(41,42,43)$. On the other hand, functional expression on neonatal $\mathrm{T}$ cells can be induced by their activation with anti-CD3 (44). Recently, we have demonstrated that cord blood $\mathrm{B}$ cells are mainly composed of $\mathrm{IgD}^{+} \mathrm{C} 27^{-}$cells, but not $\mathrm{IgD}^{-} \mathrm{CD} 27^{+} \mathrm{B}$ cells with capacity to produce $\operatorname{IgG}, \operatorname{IgM}$, and $\operatorname{IgA}$, implying that the impaired immunoglobulin secretion from cord blood cells is due to the composition of unprimed naive B cells (23). In this respect, the impairment of CD40/CD154 interaction in XHIM patients grossly inhibits the generation of $\mathrm{CD} 27^{+}$memory $\mathrm{B}$ cells. The condition is very similar to that of cord blood B cells, which may not yet be primed in the germinal center through immunoglobulin receptors and CD40.

$\operatorname{IgE}$ synthesis is preceded by transcription of the germline $\epsilon$ RNA, and the relationship between this expression and subse- quent switching to $\mathrm{C} \epsilon$ has been proposed. $\mathrm{IgD}^{+} \mathrm{CD} 27^{+}$and $\mathrm{IgD}^{+} \mathrm{CD} 27^{-} \mathrm{B}$ cells of the patient studied here, as well as healthy adults, as expected, did not differ in their ability to produce germline $\epsilon$ transcripts by exogenous IL-4. Also, antiCD40 stimulation or anti-CD40 plus CD70 transfectants did not upregulate IL-4-induced $\epsilon$ transcripts in B cell subpopulations from healthy adults even in $\mathrm{IgD}^{-} \mathrm{CD} 27^{+}$memory $\mathrm{B}$ cells (data not shown), suggesting that CD27/CD70 interactions do not participate in IL-4-induced $\epsilon$ transcripts. We have found that cross-linking through CD27 on B cells enhanced IgE synthesis by promoting the differentiation into plasma cells in the presence of IL-4 plus anti-CD40 mAb (Nagumo, H., K. Agematsu, S. Hokibara, K. Yasui, and A. Komiyama, manuscript in preparation). Therefore, the absence of $\mathrm{IgD}^{-} \mathrm{CD} 27^{+}$memory B cells in XHIM patients may contribute to the possibly impaired $\operatorname{IgE}$ synthesis.

CD40 is expressed on most B cells including naive and memory B cells. On the other hand, CD27 is expressed on memory B cells, but not on naive B cells (23). CD154 is expressed on $\mathrm{T}$ cells soon after activation, and CD70 was expressed on $\mathrm{T}$ cells later after activation (24). On the basis of these findings, mature $\mathrm{B}$ cell differentiation and immunoglobulin production are regulated by at least two of the major cell to cell signaling pathways. CD40/CD154 interactions act in an early phase of $\mathrm{B}$ cell activation and induce the expansion of a memory B cell pool. Most recently, we demonstrated that memory B cells differentiated into plasma cells by the activated helper T cells via CD27/CD70 in the presence of several cytokines such as IL-10 and IL-2 (24). These findings strongly suggest that $\mathrm{IgD}^{-} \mathrm{CD} 27^{+}$memory $\mathrm{B}$ cells are necessary to produce large amounts of immunoglobulins by differentiating into plasma cells through the contact with CD70.

In conclusion, the present data indicate that the absence of $\mathrm{IgD}^{-} \mathrm{CD} 27^{+}$memory B cells largely accounts for impaired immunoglobulin production despite functional CD40 signaling in XHIM patients.

\section{Acknowledgments}

We thank Tetsuji Kobata (Juntendo University, Tokyo, Japan) and Chikao Morimoto (University of Tokyo, Tokyo, Japan) for discussion in this study.

\section{References}

1. Rosen, F.S., S.V. Kevy, E. Merler, C.A. Janeway, and D. Gitlin. 1961. Recurrent bacterial infections and dysgamma-globulinemia: deficiency of $7 \mathrm{~S}$ $\gamma$-globulins in the presence of elevated 19S $\gamma$-globulins. Pediatrics. 28:182-195.

2. Callard, R.E., R.J. Armitage, W.C. Fanslow, and M.K. Spriggs. 1993. CD40 ligand and its role in X-linked hyper-IgM syndrome. Immunol. Today. 14:559-564.

3. Aruffo, A., M. Farrington, D. Hollenbaugh, X. Li, A. Milatovich, S. Nonoyama, J. Bajorath, L.S. Grosmaire, R. Stenkamp, M. Neubauer, et al. 1993. The CD40 ligand, gp39, is defective in activated T cells from patients with X-linked hyper-IgM syndrome. Cell. 72:291-300.

4. Allen, R.C., R.J. Armitage, M.E. Conley, H. Rosenblatt, N.A. Jenkins, N.G. Copeland, M.A. Bedell, S. Edelhoff, C.M. Disteche, D.K. Simoneaux, et al. 1993. CD40 ligand gene defects responsible for X-linked hyper-IgM syndrome. Science. 259:990-993.

5. DiSanto, J.P. J.Y. Bonnefoy, J.F. Gauchat, A. Fischer, and G. de Saint Basile. 1993. CD40 ligand mutations in X-linked immunodeficiency with hyperIgM. Nature. 361:541-543.

6. Armitage, R.J., W.C. Fanslow, L. Strockbine, T.A. Sato, K.N. Clifford, B.M. Macduff, D.M. Anderson, S.D. Gimpel, T. Davis-Smith, C.R. Maliszewski, et al. 1992. Molecular and biological characterization of a murine ligand for CD40. Nature. 357:80-82.

7. Stamenkovic, I., E.A. Clark, and B. Seed. 1989. A B-lymphocyte activa- 
tion molecule related to the nerve growth factor receptor and induced by cytokines in carcinomas. EMBO (Eur. Mol. Biol. Organ.) J. 8:1403-1410.

8. Banchereau, J., and F. Rousset. 1991. Growing human B lymphocytes in the CD40 system. Nature. 353:678-679.

9. Xu, J., T.M. Foy, J.D. Laman, E.A. Elliott, J.J. Dunn, T.J. Waldschmidt, J. Elsemore, R.J. Noelle, and R.A. Flavell. 1994. Mice deficient for the CD40 ligand. Immunity. 1:423-431.

10. van Essen, D., H. Kikutani, and D. Gray. 1995. CD40 ligand-transduced co-stimulation of $\mathrm{T}$ cells in the development of helper function. Nature. 378: 620-623.

11. Chu, Y.W., E. Marin, R. Fuleihan, N. Ramesh, F.S. Rosen, R.S. Geha, and R.A. Insel. 1995. Somatic mutation of human immunoglobulin V genes in the X-linked hyper IgM syndrome. J. Clin. Invest. 95:1389-1393.

12. Han, S., K. Hathcock, B. Zheng, T.B. Kepler, R. Hodes, and G. Kelsoe. 1995. Cellular interaction in germinal centers. Roles of CD40 ligand and B7-2 in established germinal centers. J. Immunol. 155:556-567.

13. Gray, D., P. Dullforce, and S. Jainandunsing. 1994. Memory B cell development but not germinal center formation is impaired by in vivo blockade of CD40-CD40 ligand interaction. J. Exp. Med. 180:141-155.

14. Arpin, C., J. Dechanet, C. Van Kooten, P. Merville, G. Grouard, F. Briere, J. Banchereau, and Y.J. Liu. 1995. Generation of memory B cells and plasma cells in vitro. Science. 268:720-722.

15. Nonoyama, S., M.L. Farrington, and H.D. Ochs. 1994. Effect of IL-2 on immunoglobulin production by anti-CD40-activated human B cells: synergistic effect with IL-10 and antagonistic effect with IL-4. Clin. Immunol. Immunopathol. 72:373-379.

16. Rousset, F., E. Garcia, T. Defrance, C. Peronne, N. Vezzio, D.H. Hsu, R. Kastelein, K.W. Moore, and J. Banchereau. 1992. Interleukin 10 is a potent growth and differentiation factor for activated human B lymphocytes. Proc. Natl. Acad. Sci. USA. 89:1890-1893.

17. Gascan, H., J.F. Gauchat, G. Aversa, P. van Vlasselaer, and J.E. de Vries. 1991. Anti-CD40 monoclonal antibodies or CD4 ${ }^{+} \mathrm{T}$ cell clones and IL-4 induce IgG4 and $\mathrm{IgE}$ switching in purified human B cells via different signaling pathways. J. Immunol. 147:8-13.

18. Camerini, D., G. Walz, W.A.M. Lenen, J. Borst, and B. Seed. 1991. The T cell activation antigen CD27 is a member of the nerve growth factor/tumor necrosis factor receptor gene family. J. Immunol. 147:3165-3169.

19. Goodwin, R.G., M.R. Alderson, C.A. Smith, R.J. Armitage, T. VandenBos, R. Jerzy, T.W. Tough, M.A. Schoenborn, T. Davis-Smith, K. Hennen, et al. 1993. Molecular and biochemical characterization of a ligand for CD27 defines a new family of cytokines with homology to tumor necrosis factor. Cell. 73 : $447-456$.

20. Agematsu, K., T. Kobata, K. Sugita, T. Hirose, S.F. Schlossman, and C. Morimoto. 1995. Direct cellular communication between CD45RO and CD45RA T cell subset via CD27/CD70. J. Immunol. 154:3627-3635.

21. Kobata, T., S. Jacquot, S. Kozlowski, K. Agematsu, S.F. Schlossman, and C. Morimoto. 1995. CD27 ${ }^{-}$CD70 interactions regulate B cell activation by T cells. Proc. Natl. Acad. Sci. USA. 92:11249-11253.

22. Agematsu, K., T. Kobata, F.C. Yang, T. Nakazawa, K. Fukushima, M. Kitahara, T. Mori, K. Sugita, C. Morimoto, and A. Komiyama. 1995. CD27/ CD70 interaction directly drives B cell IgG and IgM synthesis. Eur. J. Immunol. 25:2825-2829.

23. Agematsu, K., H. Nagumo, F.C. Yang, T. Nakazawa, K. Fukushima, S. Ito, K. Sugita, T. Mori, T. Kobata, C. Morimoto, and A. Komiyama. 1997. B cell subpopulations separated by CD27 and crucial collaboration of $\mathrm{CD} 27^{+} \mathrm{B}$ cells and helper T cells in immunoglobulin production. Eur. J. Immunol. 27:20732079.

24. Agematsu, K., H. Nagumo, Y. Oguchi, T. Nakazawa, K. Fukushima, K. Yasui, S. Ito, T. Kobata, C. Morimoto, and A. Komiyama. 1998. Generation of plasma cells from peripheral blood memory B cells: synergistic effect of IL-10 and CD27/CD70 interaction. Blood. 91:173-180.

25. Jacquot, S., T. Kobata, S. Iwata, C. Morimoto, and S.F. Schlossman. 1997. CD154/CD40 and CD70/CD27 interactions have different and sequential functions in T cell-dependent B cell responses: enhancement of plasma cell differentiation by CD27 signaling. J. Immunol. 159:2652-2657.

26. Nonoyama, S., M. Shimazu, H. Toru, K. Seyama, H. Nunoi, M. Neu- bauer, J. Yata, and H.D. Ochs. 1997. Mutations of the CD40 ligand gene in 13 Japanese patients with X-linked hyper-IgM syndrome. Hum. Genet. 99:624-627.

27. Sugita, K., T. Hirose, D.M. Rothstein, C. Donahue, S.F. Schlossman, and C. Morimoto. 1992. CD27, a member of the nerve growth factor receptor family, is preferentially expressed on CD45RA ${ }^{+} \mathrm{CD} 4 \mathrm{~T}$ cell clones and involved in distinct immunoregulatory functions. J. Immunol. 149:3208-3216.

28. Morimoto, C., N.L. Letvin, J.A. Distaso, W.R. Aldrich, and S.F. Schlossman. 1985. The isolation of characterization of the human suppressor inducer $\mathrm{T}$ cell subset. J. Immunol. 134:1508-1515.

29. Chomczynski, P., and N. Sacchi. 1987. Single-step method of RNA isolation by acid guanidinium thiocyanate-phenol-chloroform extraction. Anal. Biochem. 162:156-159.

30. Gussow, D., R. Rein, I. Ginjaar, F. Hochstenbach, G. Seema, A. Kottman, and H.L. Ploegh. 1987. The human $\beta 2$-microglobulin gene: primary structure and definition of the transcription unit. J. Immunol. 139:3132-3138.

31. Korthauer, U., D. Graf, H.W. Mages, F. Briere, M. Padayachee, S. Malcom, A.G. Ugazio, L.D. Notarangelo, R.J. Levinsky, and R.A. Kroczek. 1993. Defective expression of T cell CD40 ligand causes X-linked immunodeficiency with hyper-IgM. Nature. 361:539-541.

32. Saiki, O., T. Tanaka, Y. Wada, H. Uda, A. Inoue, Y. Katada, M. Izeki, M. Iwata, H. Nunoi, I. Matsuda, N. Kinoshita, and T. Kishimoto. 1995. Signaling through CD40 rescues $\mathrm{IgE}$ but not IgG and $\mathrm{IgA}$ secretion in X-linked immunodeficiency with hyper-IgM. J. Clin. Invest. 95:510-514.

33. Banchereau, J., F. Bazan, D. Blanchard, F. Briere, J.P. Galizzi, C. van Kooten, Y.J. Liu, F. Rousset, and S. Saeland. 1994. The CD40 antigen and its ligand. Annu. Rev. Immunol. 12:881-922.

34. Noelle, R.J. 1995. The role of gp39 (CD40L) in immunity. Clin. Immunol. Immunopathol. 76:203-207.

35. Durandy, A., C. Schiff, J.Y. Bonnefoy, M. Forveille, F. Rousset, G. Mazzei, M. Milili, and A. Fischer. 1993. Induction by anti-CD40 antibody or soluble CD40 ligand and cytokines of $\operatorname{IgG}, \operatorname{IgA}$, and $\operatorname{IgE}$ production by B cells from patients with X-linked hyper IgM syndrome. Eur. J. Immunol. 23:22942299.

36. Fuleihan, R., N. Ramesh, R. Loh, H. Jabara, R.S. Rosen, T. Chatila S.M. Fu, I. Stamenkovic, and R.S. Geha. 1993. Defective expression of the CD40 ligand in X chromosome-linked immunoglobulin deficiency with normal or elevated IgM. Proc. Natl. Acad. Sci. USA 90:2170-2173.

37. Foy, T.M., F.H. Durie, and R.J. Noelle. 1994. The expansive role of CD40 and its ligand, gp39, in immunity. Semin. Immunol. 6:259-266.

38. Durandy, A., C. Hivroz, F. Mazerolles, C. Schiff, F. Bernard, E. Jouanguy, P. Revy, J.P. DiSanto, J.F. Gauchat, J.Y. Bonnefoy, J.L. Casanova, and A. Fischer. 1997. Abnormal CD40-mediated activation pathway in B lymphocytes from patients with hyper-IgM syndrome and normal CD40 ligand expression. $J$. Immunol. 158:2576-2584.

39. Durandy, A., C. Schiff, J.Y. Bonnefoy, M. Forveille, F. Rousset, G. Mazzei, M. Milili, and A. Fischer. 1993. Induction by anti-CD40 antibody or soluble CD40 ligand and cytokines of $\mathrm{IgG}, \mathrm{IgA}$ and $\mathrm{IgE}$ production by B cells from patients with X-linked hyper IgM syndrome. Eur. J. Immunol. 23:2294 2299.

40. Callard, R.E., S.H. Smith, J. Herbert, G. Morgan, M. Padayachee, S. Lederman, L. Chess, R.A. Kroczek, W.C. Fanslow, and R.J. Armitage. 1994 CD40 ligand (CD40L) expression and B cell function in a gammaglobulinemia with normal or elevated levels of IgM (HIM). Comparison of X-linked, autosomal recessive, and non-X-linked forms of the disease, and obligate carriers. $J$. Immunol. 153:3295-3306.

41. Splawski, J.D., D.F. Jelinek, and P.E. Lipsky. 1991. Delineation of the functional capacity of human neonatal lymphocytes. J. Clin. Invest. 87:545-553.

42. Nonoyama, S., L.A. Penix, C.P. Edwards, D.B. Lewis, S. Ito, A. Aruffo, C.B. Wilson, and H.D. Ochs. 1995. Diminished expression of CD40 ligand by activated neonatal T cells. J. Clin. Invest. 95:66-75.

43. Fuleihan, R., D. Ahern, and R.S. Geha. 1994. Decreased expression of the ligand for CD40 in newborn lymphocytes. Eur. J. Immunol. 24:1925-1928.

44. Splawski, J.B., J. Nishioka, Y. Nishioka, and P.E. Lipsky. 1996. CD40 ligand is expressed and functional on activated neonatal T cells. J. Immunol. 156:119-127. 